\section{Teknik Sipil Untuk Masyarakat}

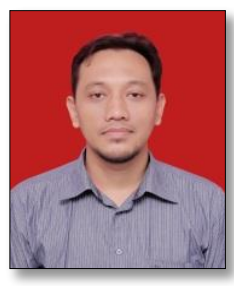

Sanitasi yang sehat adalah sebuah kebutuhan pokok bagi manusia dan lingkungan, sebab kondisi sanitasi mencerminkan baik atau buruknya kesehatan manusia dan lingkungan setempat.

Program SANIMAS (Sanitasi Berbasis Masyarakat) adalah Program perbaikan sanitasi masyarakat dari Kementerian PUPR yang dikendalikan oleh Satker PSPLP dan FasProv di Provinsi seluruh Indonesia.

Pelaksanaan Program SANIMAS ini direncanakan, dilaksanakan, dimanfaatkan, dan dipelihara oleh Masyarakat dengan didampingi oleh Tenaga Fasilitator Lapangan (TFL) Teknik dan Pemberdayaan dalam satu tim.

www.buletinppi.ulm.ac.id

\section{Pendahuluan}

Hasil Riset Kesehatan Dasar (Riskesdas), yang terakhir dilakukan pada tahun 2013, menunjukkan bahwa $76,2 \%$ rumah tangga di Indonesia telah memiliki fasilitas buang air besar (BAB) pribadi. Namun, masih terdapat $12,9 \%$ rumah tangga yang mempraktikkan aktivitas $B A B$ sembarangan. Dari fasilitas $B A B$ tersebut, hanya $15,5 \%$ saja yang menyalurkan air buangan menggunakan penampungan tertutup di pekarangan yang dilengkapi IPAL. Sebagian besar masih mengalirkannya langsung ke lingkungan tanpa diproses terlebih dahulu.

Tak heran jika World Bank dalam publikasinya pada tahun 2013 menyatakan bahwa 95\% dari tangki septik bocor dan mengakibatkan pencemaran air tanah (WSP, 2013).

Berdasarkan pemantauan yang dilakukan oleh Kementerian Lingkungan Hidup terhadap kualitas air sungai di hampir 57 sungai di 33 provinsi selama kurun waktu 2008-2013, diketahui bahwa $70-75 \%$ sungai yang dipantau telah tercemar, baik tercemar ringan, sedang, maupun berat. Penyebab utama pencemaran air sungai tersebut adalah limbah domestik.

Fakta-fakta di atas menempatkan Indonesia sebaga negara dengan sanitasi terburuk kedua di dunia setelah India (UN, 2013).

Tanpa disadari, kerugian ekonomi global terkait kurangnya akses terhadap fasilitas sanitasi diperkirakan mencapai 260 miliar dolar per tahun (World Bank, 2013). Lebih spesifik lagi, kerugian ekonomi yang dialami Indonesia akibat sanitasi buruk berdasarkan estimasi pada tahun 2006 mencapai 6,3 miliar dolar per tahun atau sama dengan 2,3\% dari produk domestik bruto Indonesia pada tahun tersebut (WSP, 2008). Kerugian ekonomi yang dimaksud ialah biaya yang dikeluarkan untuk mengobati penyakit serta biaya yang disebabkan oleh penurunan produktifitas penderita penyakit akibat sanitasi buruk.

\section{Realisasi Kegiatan}

Program Sanitasi oleh Masyarakat (Sanimas) merupakan Program Sanitasi dari Pemerintah melalui pemberdayaan masyarakat yang berada dilingkungan pemukiman padat. Melalui Program Sanimas ini, masyarakat dapat memilih sendiri program pembangunan prasarana dan sarana air limbah pemukiman (khususnya pembuangan limbah rumah tangga) yang sesuai, dapat ikut aktif menyusun rencana pelaksanaan, membentuk kelompok dan melakukan pembangunan fisik termasuk mengelola kegiatan operasi dan pemeliharaannya bahkan bila perlu dapat mengembangkannya.

Adanya perubahan perilaku dari masyarakat (pemanfaat program Sanimas) yang dulu kurang perdul menjadi lebih perduli terhadap bahaya pencemaran dari tinja manusia terhadap lingkungan sekitar (badan air) dan kesehatan manusia. Kemudian dilanjutkan dengan pembangunan fisik prasarana dan sarana dari sanimas tersebut, yaitu pembangunan IPAL (sesuai dengan jumlah pengguna/volume) dan pembangunan jaringan perpipaan dari rumah kerumah yang akhir dari pipa tersebut masuk ke IPAL kemudian diproses secara anaerobik oleh bakteri pengurai sebelum dialirkan kesungai atau diresapkan kedalam tanah.

\section{Proses Singkat Kegiatan SANIMAS (Sanitasi Berbasis Masyarakat)}

Lokasi kegiatan SANIMAS didapatkan dari hasi survey dan buku putih sanitasi Kabupaten.

Kemudian dilaksanakan Pengumpulan Data dan Pengukuran Dalam Perencanaan Sistem IPAL Komunal.

\section{Pengumpulan Data :}

a. Data yang dikumpulkan digunakan sebagai bahan perhitungan desain IPAL

b. Memudahkan dalam perencanaan komponen pendukungnya

c. Mengetahui kondisi riil di lapangan yang bisa disesuaikan untuk proses perencanaan dan pelaksanaan pembangunan

d. Mengetahui kelayakan teknis lokasi IPAL

\section{Cara Pengumpulan Data}

a. Survey Lokasi, melihat secara fisik kondisi di lapangan

b. Wawancara dengan masyarakat, calon penerima manfaat atau sumber informasi lainnya

c. Referensi (buku-buku, contoh pelaksanaan yang sudah ada), standar-standar yang berlaku 


\section{Informasi yang dibutuhkan}

a. Calon Pengguna

- Jumlah KK : ........... KK

- Jumlah Rumah : :.......... Unit

- Jumlah jiwa : :......... Orang

b. Jenis Limbah

\begin{tabular}{|l|l|}
\hline \multicolumn{1}{|c|}{ Asal Limbah } & \multicolumn{1}{|c|}{$\begin{array}{c}\text { Kondisi sistem } \\
\text { pengolahan yang sudah } \\
\text { ada }\end{array}$} \\
\hline $\begin{array}{l}\text { Kamar Mandi } \\
\text { Berapa persentase atau } \\
\text { jumlah KK yang mempunyai }\end{array}$ & \\
\hline $\begin{array}{l}\text { WC } \\
\text { Berapa persentase atau } \\
\text { jumlah KK yang mempunyai } \\
\text { WC }\end{array}$ & \\
\hline $\begin{array}{l}\text { Dapur } \\
\text { Bagaimana pengelolaan } \\
\text { minyak (dibuang langsung } \\
\text { ke saluran pembuangan } \\
\text { atau ditampung) }\end{array}$ & \\
\hline $\begin{array}{l}\text { Mencuci (untuk komunal) } \\
\text { Bagaimana pemakaian } \\
\text { detergen/sabun (jenis dan } \\
\text { jumlah) }\end{array}$ & \\
\hline
\end{tabular}

c. Sumber Air

1) Sumur

- Jumlah/rasio pengguna:

- Kualitas air

- Warna :

- Bau

- Rasa :

- Ecoli :

- Kedalaman muka air tanah pada musim hujan :...m

- Kedalaman muka air tanah pada musim kemarau: ...m

2) Sumber air lainnya:

- ( ) PDAM

-( ) sumber air tanah

- ( ) lainnya

\section{d. Ketersediaan Lahan}

1) Menunjukkan bukti bahwa tanah bisa dipakai untuk Lahan IPAL dan diketahui oleh Lurah dan Camat

a. ( ) Sertifikat hak milik

b. ( ) Surat akta jual beli

c. ( ) Hak guna bangunan/usaha

d. ( ) Hibah

e. ( ) lainnya, sebutkan

2) Luas (Dimensi)

:..........m2

3) Fungsi lahan eksisting

4) Jarak dengan sumber air terdekat (sumur/sumber air lainnya)

5) Jarak dengan bangunan terdekat

.........m

6) Jalan akses

.........m

e. Potensi Banjir

1) Frekuensi banjir

2) Muka air banjir di lahan sekarang :

3) Muka air tanah (lihat pada sumur terdekat/berapa meter mereka gali tanah sampai keluar air) $\quad$ :........... $\mathrm{m}$

4) Lama genangan banjir (durasi) :

f. Jenis tanah
1) ( ) biasa
2) ( ) liat
3) ( ) padas
4) ( ) berbatu
5) ( ) pasir
6) ( ) lumpur
7) ( ) gambut

g. Akses untuk logistik konstruksi dan pengurasan/penyedotan lumpur ke lokasi IPAL
1) Lebar jalan $m$
2) Jarak dari jalan besar

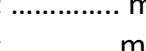
3) apakah ada jasa sedot tinja?

h. Jarak rumah terjauh dari lahan

(yang akan dilayani melalui fasilitas pengolahan air limbah) : ... m

i. Letak/Posisi Lahan (Lay Out)

j. Pemanfaatan atau Penyaluran Efluen IPAL

$k$. Elevasi area yang dilayani

Elevasi tanah,

( ) Datar (gradien kurang dari 0,5\%)

( ) Gradien sedang 0,5 - 1\%

( ) Gradien curam > 1\%

\section{Tenaga Kerja}

Kemudahan untuk mendapatkan tenaga kerja (beri tanda $\mathrm{V}$ ):

- Mudah( )

- Sulit ( )

\section{m. Sketsa Area Pelayanan Hasil Survey}

n. Potensi dan Harga Satuan Material Setempat

1) Harga satuan

2) Jenis material setempat

\section{Pengukuran :}


Pengukuran elevasi dan jarak bisa menggunakan Alat Theodolit, Meteran, dan Water Pass dari selang air. Tergantung kondisi dilapangan.
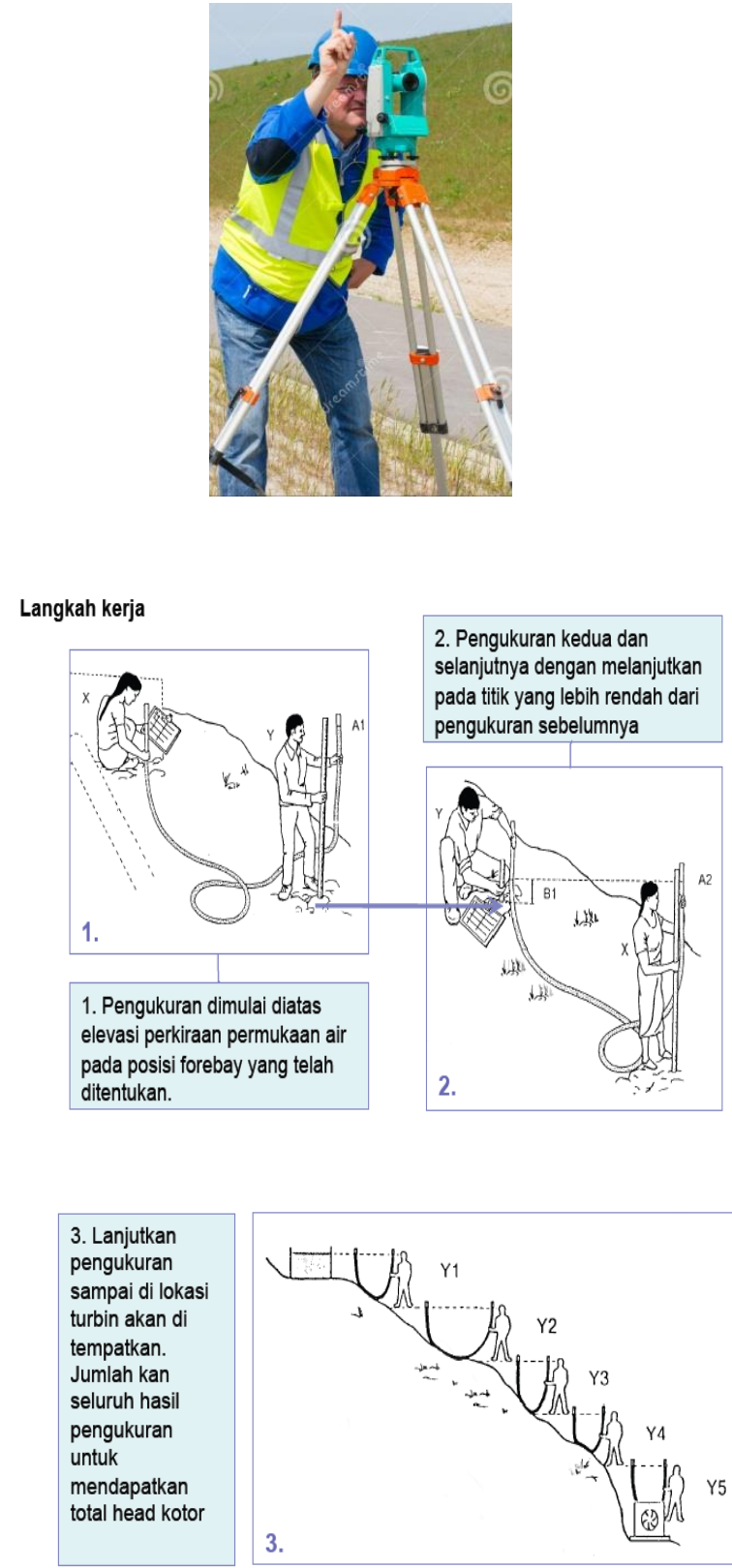

\section{Hasil Survei Dan Pengukuran}

Sebuah peta yang lengkap dengan panjang jarak, elevasi titik titik, sketsa tata letak bangunan dan pohon

Dari hasil tersebut, diharapkan bisa dicapai suatu perencanaan sistem perpipaan IPAL Komunal yang efektif dan efisien, serta didapatkan kuantitas dan volume dari :

- panjang pipa dengan diameternya,

- jumlah manhole,

- bak kontrol

- kebutuhan lain: adanya sambungal PLN, pompa
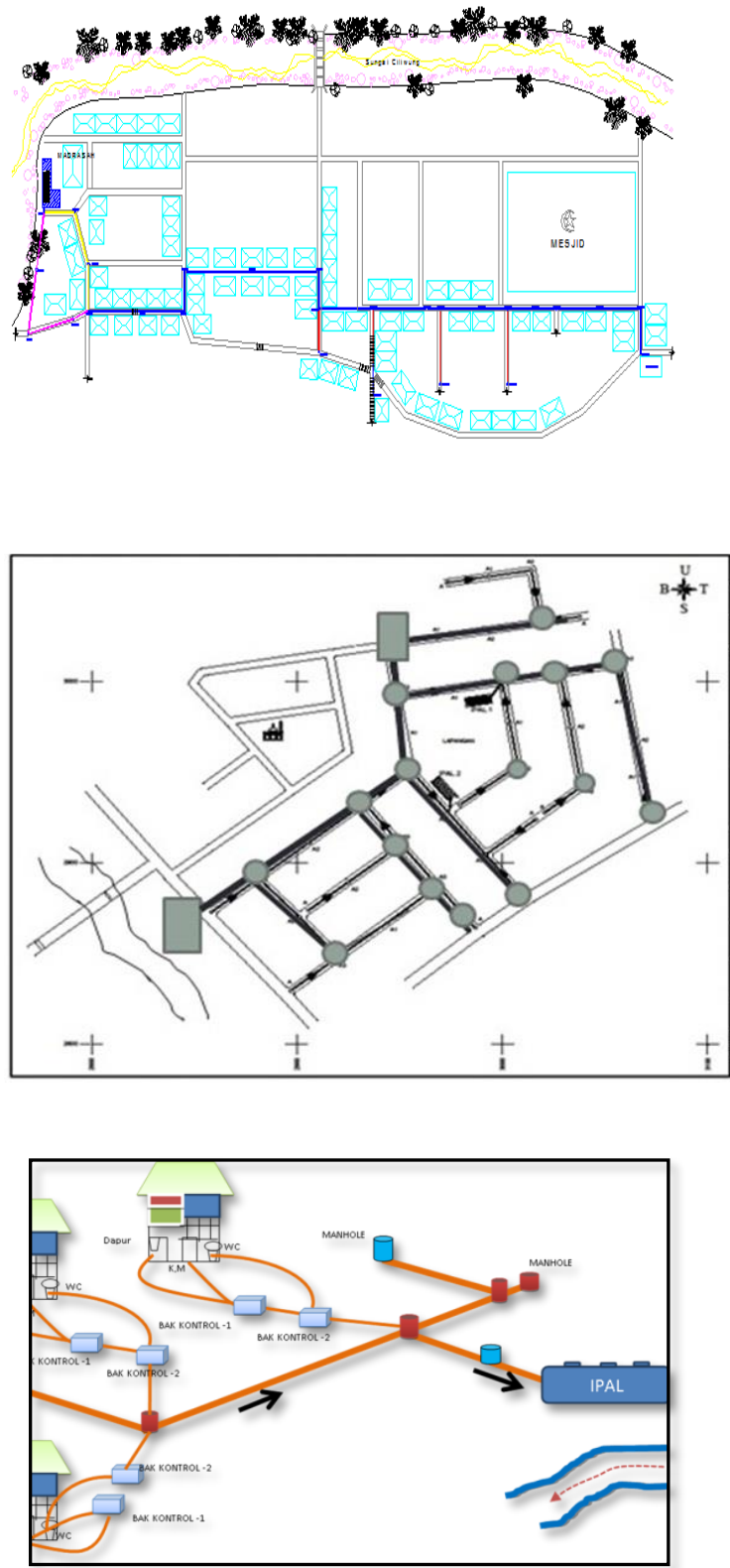

\section{Kesimpulan}

Program SANIMAS (Sanitasi Berbasis Masyarakat) adalah suatu usaha penyehatan manusia dan lingkungan dengan pembenahan sanitasi melalui Pemberdayaan Masyarakat (dari dan untuk masyarakat) sehingga tumbuh rasa memiliki oleh masyarakat terhadap fasilitas yang dibangun oleh Pemerintah, dan semua kegiatan dari perencanaan, pelaksanaan, dan pemeliharaan dilaksanakan oleh Masyarakat dengan didampingi oleh Fasilitator Lapangan Teknik dan Pemberdayaan. 


\section{Ucapan Terimakasih}

Ucapan terimakasih ditujukan kepada:

1. Allah SWT atas segala bimbingan, karunia, dan nikmat NYA ;

2. Keluarga Penulis atas segala dukungannya baik berupa moril maupun materil ;

3. Kasatker PSPLP Prov. Kalimantan Selatan beserta seluruh Staff dan FasProv Kalimantan Selatan, atas segala ilmu dan bimbingannya ;

4. Ketua Prodi PPI Unlam beserta seluruh Dosen, Dosen Penguji, dan Staff, atas segala dukungan, bimbingan, dan ilmunya ;

5. Rekan-rekan Program Profesi Insinyur.

\section{Referensi}

1 "KLH Melakukan Pemantauan Kwalitas Air Sungai di 33 Provinsi", http://www.menlh. go.id/klhmelakukan-pemantauan-kwalitas-air-di-33-provinsi/, diakses 16 Januari 2017.

2 "Sanitasi Buruk Menghambat Potensi Pertumbuhan Indonesia", http:// www.worldbank.org/in/news/pressrelease/2013/10/28/Poor-Sanitation- ImpedesIndonesia-8217-s-Growth- Potential, diakses 16 Januari 2017.

3 Badan Penelitian dan Pengembangan Kesehatan Kementerian Kesehatan RI, 2013, Riset Kesehatan Dasar Tahun 2013. 